\title{
Yearbook of Morphology
}

Editors:

Geert Booij

Jaap van Marle

Consulting Editors: Stephen Anderson (Baltimore)

Mark Aronoff (Stony Brook, N.Y.)

Laurie Bauer (Wellington)

Mark Baker (Montreal)

Rudie Botha (Stellenbosch)

Joan Bybee (Albuquerque, N.M.)

Andrew Carstairs-McCarthy

(Christchurch)

Wolfgang Dressler (Wien)

Jack Hoeksema (Groningen)

Rochelle Lieber (Durham, N.H.)

Peter Matthews (Cambridge, U.K.)

Franz Rainer (Salzburg)

Sergio Scalise (Bologna)

Henk Schultink (Utrecht)

Arnold Zwicky (Columbus, Ohio/

Stanford)

Editorial address: Editors, Yearbook of Morphology

Vakgroep Taalkunde, Vrije Universiteit

De Boelelaan 1105

1081 HV Amsterdam, The Netherlands

e-mail: booij@jet.let.vu.nl 


\section{YEARBOOK OF MORPHOLOGY \\ 1993}

Edited by

GEERT BOOIJ

General Linguistics, Free University, Amsterdam/Holland Institute of generative Linguistics

JAAP VAN MARLE

P.J. Meertens Institute of the Royal Academy of Sciences

KLUWER ACADEMIC PUBLISHERS

DORDRECHT / BOSTON / LONDON 
Published by Kluwer Academic Publishers, P.O. Box 17, 3300 AA Dordrecht, The Netherlands.

Kluwer Academic Publishers incorporates the publishing programmes of D. Reidel, Martinus Nijhoff, Dr W. Junk and MTP Press.

Sold and distributed in the U.S.A. and Canada by Kluwer Academic Publishers,

101 Philip Drive, Norwell, MA 02061, U.S.A.

In all other countries, sold and distributed

by Kluwer Academic Publishers Group,

P.O. Box 322, 3300 AH Dordrecht, The Netherlands.

Printed on acid-free paper

All rights reserved

(C) 1993 by Kluwer Academic Publishers

No part of the material protected by this copyright notice may be reproduced or utilized in any form or by any means, electronic or mechanical, including photocopying, recording or by any information storage and retrieval system, without written permission from the copyright owner.

Printed in the Netherlands 


\section{Table of contents}

THOMAS BECKER / Back-formation, cross-formation, and 'bracketing 1 paradoxes' in paradigmatic morphology

GEERT BOOIJ / Against split morphology

ROCHELLE LIEBER and HARALD BAAYEN / Verbal prefixes in

Dutch: a study in lexical conceptual structure

JOHN J. MCCARTHY and ALAN PRINCE / Generalized Alignment 79

CAROLINE SMITS / Resistance to erosion in American Dutch inflection 155

RICHARD SPROAT and CHILIN SHIH / Why Mandarin morphology 185 is not stratum-ordered

IRENE VOGEL / Verbs in Italian morphology

\section{Short notice}

JAAP VAN MARLE / Morphological adaptation

\section{Book notices}

MARK ARONOFF/ Peter Matthews, Morphology: An Introduction 267 to Word Structure. Second edition

GEERT BOOIJ/Sergio Scalise (ed.) The Morphology of Compounding 269

MICHAEL HAMMOND / Andrew Spencer, Morphological Theory 269

FRANZ RAINER/Yakov Malkiel, Diachronic Studies in Lexicology, 272 Affixation and Phonology 


\title{
Against split morphology
}

\author{
GEERT BOOIJ
}

\section{INTRODUCTION}

The traditional distinction between inflection and derivation has been widely discussed in the morphological literature (cf. Plank 1981, Anderson 1982, 1988a,b; 1992, Bybee 1985, Watters 1985, Scalise 1986, Badecker and Caramazza 1989, Dressler 1989). Anderson argues for a separation of derivation and inflection in the grammar, where inflection is delimited from derivation by the following definition:

"Inflectional morphology is what is relevant to the syntax" (Anderson 1982: 587)

This distinction is accounted for in the organization of the grammar by locating derivational rules in the lexicon, and inflectional rules in a post-syntactic component of spell-out rules that derive the correct form of words on the basis of their morpho-syntactic properties which are partially determined by syntactic rules of agreement and case assignment. The hypothesis that derivation and inflection are separated in the grammar is called the 'split morphology hypothesis' (Perlmutter 1988).

As evidence for split morphology Anderson (1982: 610) adduces the observation that (regular) inflectional morphology is always peripheral with respect to derivational morphology, which is predicted by the proposed organization of the grammar. To put it differently, (regular) inflection cannot function as input for derivation.

In this paper I will argue against the split morphology hypothesis by showing that inflection can feed word formation (both derivation and compounding). I will propose a distinction between two types of inflection, inherent inflection and contextual inflection, and show that it is only certain types of inherent inflection that can feed word formation. Section 2 introduces and motivates the distinction between inherent and contextual inflection. It appears that this distinction is also reflected by processes of lexicalization and language change, and by generalizations concerning affix ordering and agreement patterns. In section 3 I will provide evidence for the claim that inherent inflection can feed word formation, which thus refutes the split morphology hypothesis. In section 4 it is shown that this generalization concerning the interaction of inflection and word formation cannot be expressed by splitting inflection into two components (inherent inflection in the lexicon, and contextual inflection in a post-syntactic component of spell-out rules). Instead, we need substantive constraints on the interaction of inflection and word formation. Such constraints are proposed in section 5 . 


\section{INHERENT AND CONTEXTUAL INFLECTION}

Anderson (1988a: 25, 1988b; 167-168) provides the following classification of inflectional categories:

(2) a. configurational categories (e.g. case marking on nouns), assigned on the basis of the larger structure in which the word appears

b. agreement categories (aspect of a word's form determined by other words in the same structure)

c. phrasal categories (e.g. case marking of an NP realized on its nominal head

d. inherent categories (e.g. number of nouns)

I will refer to the categories (2a-c) as contextual inflection, and to the category (2d) as inherent inflection.

There are also inherent morpho-syntactic properties of words that are not expressed morphologically on these words, but do play a role in contextual inflection. For instance, gender is an inherent morphosyntactic category for Dutch nouns, but it is not an inflectional category for this word class: the gender of nouns only plays a role in contextual inflection.

In Anderson's theory of inflection, the inherent morpho-syntactic features of words are generated by Complex Symbols creating rules such as

$$
\mathrm{N} \rightarrow[\alpha \text { plu, } \beta \text { neut }]
$$

(where [plu] is the feature for the category number, and [neut] the feature for the category gender). Contextually determined morphosyntactic features will be assigned by syntactic rules of case assignment, agreement, etc.. At the level of surface structure each lexical node possesses an array of relevant morphosyntactic features, on which the spell out rules operate. The array of features is in essence an unordered list, except for features for subject and object agreement (w.r.t. number and person) which may appear in a layered structure. For instance, an $\mathrm{N}$ node may contain both a feature for case and for number, without any indication of the fact that the number feature is inherent, and the case feature assigned by a syntactic rule. In other words, Anderson's theory does not predict anything about the order of inflectional affixes, although there are certainly cross-linguistic generalizations to be made here, as will be shown below, a point also made in Baker (1991).

Thus, the organizational model of the grammar that Anderson proposes is the following (from Anderson 1982: 594). 
(4)

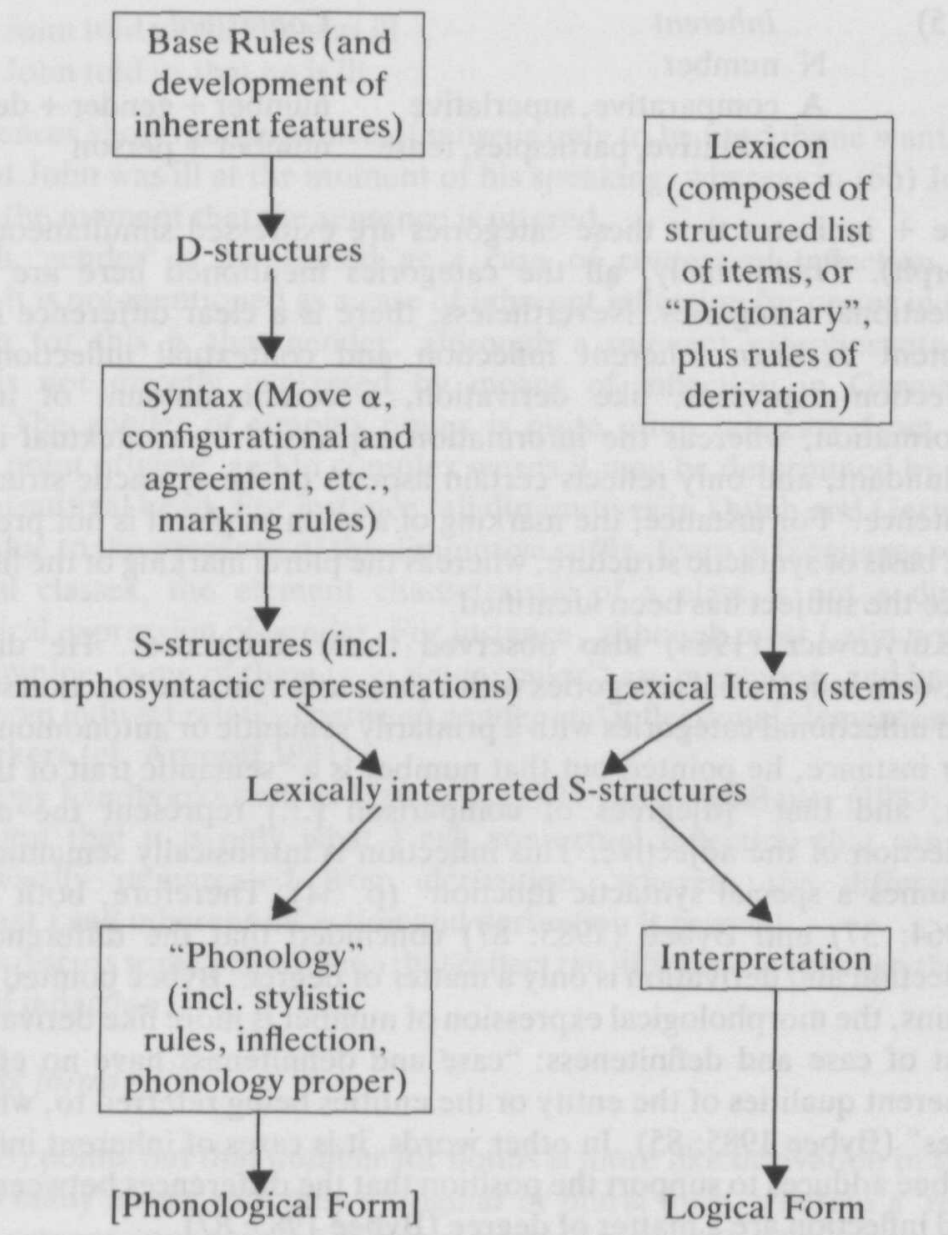

It should be realized that there is no reason why inherent inflection (i.e. the morphological expression of inherent morpho-syntactic properties) should be spelled out post-syntactically, together with contextual inflection. Lexical items could also be inherently inflected in the lexicon, and then be inserted (in D-structure or in S-structure). This latter option (inherent inflection in the lexicon) is even the only possible one if syntactic structure is not generated by rewriting rules (including the rules that expand lexical nodes into complex symbols, which are arrays of inherent morpho-syntactic properties), but is seen as the projection of properties of lexical items.

In order to make the discussion more concrete, let me first give a survey of inherent inflection versus contextual inflection for Dutch: 


$\begin{array}{ll}\text { Inherent } & \text { Contextual } \\ \mathrm{N} \text { number } & \\ \mathrm{A} \text { comparative, superlative } & \text { number + gender + definiteness } \\ \mathrm{V} \text { infinitive, participles, tense } & \text { number + person }\end{array}$

(the + indicates that these categories are expressed simultaneously by one morph). Traditionally, all the categories mentioned here are considered inflectional categories. Nevertheless, there is a clear difference in semantic content between inherent inflection and contextual inflection. Inherent inflection expresses, like derivation, a certain amount of independent information, whereas the information expressed by contextual inflection is redundant, and only reflects certain aspects of the syntactic structure of the sentence. ${ }^{1}$ For instance, the marking of a noun as plural is not predictable on the basis of syntactic structure, whereas the plural marking of the finite verb is, once the subject has been identified. ${ }^{2}$

Kuryłowicz (1964) also observed these differences. He distinguished between inflectional categories with a primarily syntactic function such as case, and inflectional categories with a primarily semantic or autonomous function. ${ }^{3}$ For instance, he pointed out that number is a "semantic trait of the noun (p. 31 ), and that "[d]egrees of comparison [...] represent the autonomous inflection of the adjective. This inflection is intrinsically semantic and never assumes a special syntactic function" (p. 34). Therefore, both Kurytowicz (1964: 37) and Bybee (1985: 87) concluded that the difference between inflection and derivation is only a matter of degree. Bybee pointed out that for nouns, the morphological expression of number is more like derivation, unlike that of case and definiteness: "case and definiteness have no effect on the inherent qualities of the entity or the entities being referred to, while number does" (Bybee 1985: 85). In other words, it is cases of inherent inflection that Bybee adduces to support the position that the differences between derivation and inflection are a matter of degree (Bybee 1985: 87).

It should also be observed that inherent inflection changes the meaning of words: a singular noun differs in meaning from a plural noun, and a comparative form of an adjective has a meaning other than that of its base form. ${ }^{4}$ In the case of infinitives and participles even change of syntactic category is involved since infinitives behave simultaneously as verbs and as nouns, not only as verbs, and participles have adjectival properties besides verbal properties.

Tense is also an inherent property of verbs, i.e. the tense of the verb is not determined by syntactic structure. ${ }^{5}$ The meaning of tense is a deictic/referential one: tense has scope over a whole clause, and locates the time of the state or action expressed by the sentence with respect to the time of speaking (Jakobson 1957, Kuryłowicz 1964: 24). In embedded clauses tense may be determined by that of the main clause (sequence of tense). However, Kurytowicz (1964: 24) pointed out that this is a secondary (syntactic) use of tense. But even in that case, there is a choice for the speaker. Compare the following sentences: 
(6) a. John told us that he was ill

b. John told us that he is ill

These sentences show that sequence of tense is only to be used if one wants to express that John was ill at the moment of his speaking, whereas in (6b) John is still ill at the moment that the sentence is uttered.

Although 'gender' is mentioned as a case of contextual inflection for adjectives, it is not mentioned as a case of inherent inflection for nouns in (5). The reason for this is that gender, although a relevant morphosyntactic category, is not directly expressed by means of inflection in Germanic languages. The gender of simplex nouns is quite often arbitrary from the synchronic point of view, and in complex words it may be determined by the derivational suffixal head. For instance, all diminutives in Dutch and German are neuter due to the presence of the diminutive suffix. Even in languages with declensional classes, the element characteristic of a class is not a direct morphological expression of gender. For instance, although most Latin nouns in $-a$ are feminine, some of them (e.g. nauta 'sailor') are masculine, and hence there is only an indirect relation between gender and inflectional elements such as class markers (cf. Aronoff 1991).

Morphology handbooks such as Matthews (1974: 46ff) and Bauer (1983: 24) also point out that it is only what I call contextual inflection that can be straightforwardly demarcated from derivation, whereas the difference between what I call inherent inflection and derivation is gradual.

I will now discuss some phenomena that reflect the differences between these two kinds of inflection.

\subsection{Lacking forms}

Bybee (1985) points out that number for nouns is more like derivation in that English has many nouns with only a singular or plural form, whereas a 'real' inflectional category must have full lexical generality (p. 84). The same point was made by Beard (1982). It also applies to Dutch nouns: in addition to the well-known pluralia tantum such as notulen 'minutes' and Alpen 'Alps' there are many nouns that lack a plural form, in particular mass nouns, abstract nouns, and proper names such as the names of the months, in short, non-count nouns: ${ }^{6}$

aplomb 'id.', arbeid 'labour', antiek 'antiques', genade 'grace', goud 'gold', Maart 'March', verzekerdheid 'assuredness'

In this respect nouns differ from verbs which usually have a complete paradigm, although occasional defective verbal paradigms have been observed (for instance, for Russian by Halle 1973).

Adjectives behave similarly to nouns in that there are also adjectives that lack certain inherent inflectional forms. For instance, certain adjectives that express a non-gradable quality (gouden 'golden', dood 'dead', oneindig 'infinite', dagelijks 'daily', mondeling 'oral', hypermodern 'very modern') do 
not have comparative and superlative forms. Vice versa, certain adjectives only occur in a superlative form, i.e. the positive degree and the comparative degree are lacking: ${ }^{7}$

(8) onder-st 'lowest', boven-st 'uppermost', uiter-st 'most extreme', voor-st 'most forward', achter-st 'most backwards', middel-st 'middle'

There are also many participles in Dutch that lack a verbal base, for instance:

$$
\text { getogen 'educated', geboren 'born', belabberd 'bad', geronnen }
$$
'clotted', geoorloofd 'permitted', geparenteerd 'related'

In this respect they resemble derived words that contain an affix, but do not have an identifiable lexical item as their base, the so-called formally complex words (cf. Booij 1977: 29-30).

\subsection{Inflectional split}

The differences between nominal and verbal number as inherent versus contextual inflection is also reflected by their differential behaviour with respect to inflectional split, the phenomenon that inflectionally related word forms receive different interpretations: we find inflectional split for singular versus plural nouns, but not for singular verb forms versus plural verb forms. Examples of inflectional split are the following:

$$
\begin{aligned}
& \text { English } \\
& \text { brother } \\
& \text { cloth 'woven material' } \\
& \text { Dutch } \\
& \text { vader 'father' } \\
& \text { letter 'id.' } \\
& \text { zenuw 'nerve' } \\
& \text { brethren 'members of a religious } \\
& \text { community' } \\
& \text { clothes 'garments' } \\
& \text { vaderen 'forefathers' } \\
& \text { letteren 'Arts' } \\
& \text { zenuwen 'a fit of nerves' }
\end{aligned}
$$

This observation supports the idea that inherent inflection is more like derivation since derived words may also have a semantically partially opaque relation to their base words.

\subsection{Deflection}

Inherent and contextual inflection behave differently in case of deflection. Kiparsky (1972: 92) already observed that in the case of nominal paradigms grammatical case is weaker than pluralization in that "lost plural distinctions are more likely to be analogically restored than lost [grammatical] case distinctions". Kiparsky also distinguished between weak inflection (grammatical case and verbal agreement in non-Pro drop-languages) versus 
strong inflection (number, tense, gender and verb agreement in Pro droplanguages), where 'weak' means 'easily subject to morphological erosion'. Kiparsky concluded: "Evidently the weak categories are those which register information that is relatively redundant" (Kiparsky 1972: 99). It will be clear that Kiparsky's distinction between weak and strong inflection coincides with that between contextual and inherent inflection.

The generalization that nominal and verbal pluralization behave differently when a language is subject to deflection can also be illustrated for Afrikaans. In Afrikaans, a daughter of Dutch, the morphological expression of number and person on verbs has been lost completely, whereas number is still expressed systematically on nouns. For verbs, the tense distinctions of Dutch are preserved although past tense is now expressed by a periphrastic form (auxiliary + past participle), the formal equivalent of the Dutch present perfect form. This pattern of deflection is understandable given the different functions of noun pluralization and verb pluralization: it is only the latter which, due to its contextual nature, is redundant, and hence can be more easily omitted. Given its independent deictic function, tense is expected to be preserved, as is indeed the case.

Interestingly, the same differentiation is found in the deflection processes of American Dutch (Van Marle and Smits 1992). Van Marle and Smits found for all the different varieties of American Dutch that pluralization of nouns is stable, whereas the verbal system has been strongly deflected in that number and person distinctions have been lost. As is to be expected if tense is a case of inherent inflection, tense may behave differently from number and person under deflection. In Old New York Dutch, person and number are lost, while the past tense forms are maintained and regularized. This does not mean that tense distinctions are never lost in deflection processes, but that there is a clear difference here between the categories of person and number versus the category of tense in that person and number distinctions are lost much more easily. In some varieties of American Dutch we also find the infinitive form as the general form for all persons and both numbers, i.e. the infinitive form, a case of inherent inflection, is maintained.

A similar situation obtains for situations of language death. Dorian (1981) reports for Scottish Gaelic that case and verbal number are highly unstable, but that nominal number is stable. Tense (and passive) morphology are maintained. In young people's Dyirbal (Schmidt 1985) case markers, some tense markers and other verbal inflectional markers tend to disappear, but some mood and aspect markers survive, i.e. contextual inflection is to a far more higher degree subject to morphological erosion.

In recent work on the evolution of the nominal paradigm in medieval Dutch Marynissen (1992) found that in the phonological restructuring of nominal paradigms maintenance of the distinction between singular and plural is given priority above maintaining case distinctions, in line with the observations given above. Similar findings were already reported in Kiparsky (1972). Romance languages such as French, Italian, and Spanish also illustrate this point: they 
lost case, but kept number as an inflectional category.

Another relevant observation is that in Afrikaans the other types of inherent inflection listed in (5), comparatives, superlatives, infinitives and participles are all maintained. On the other hand, the contextual inflection of adjectives, like that of verbs, has been subject to change. In the original Dutch system, a suffix $-e$ is added to an attributively used adjective unless the NP in which the adjective occurs has the morphosyntactic features [-def, -plu, -neut]. In the system of Afrikaans, this system has changed and demorphologized: the addition of $-e$ in attributive position is determined by the phonological make up of the adjectives, and is partially also lexically governed (Barnes 1991, Combrink 1990, Lass 1990).

\subsection{Lexicalization}

Above I pointed out that plural forms of nouns may have idiosyncratic interpretations. This also applies to inherently inflected forms of adjectives and verbs. Note, however, that this does not apply to tensed verbal forms.

Some comparative and superlative forms of adjectives have idiosyncratic interpretations:

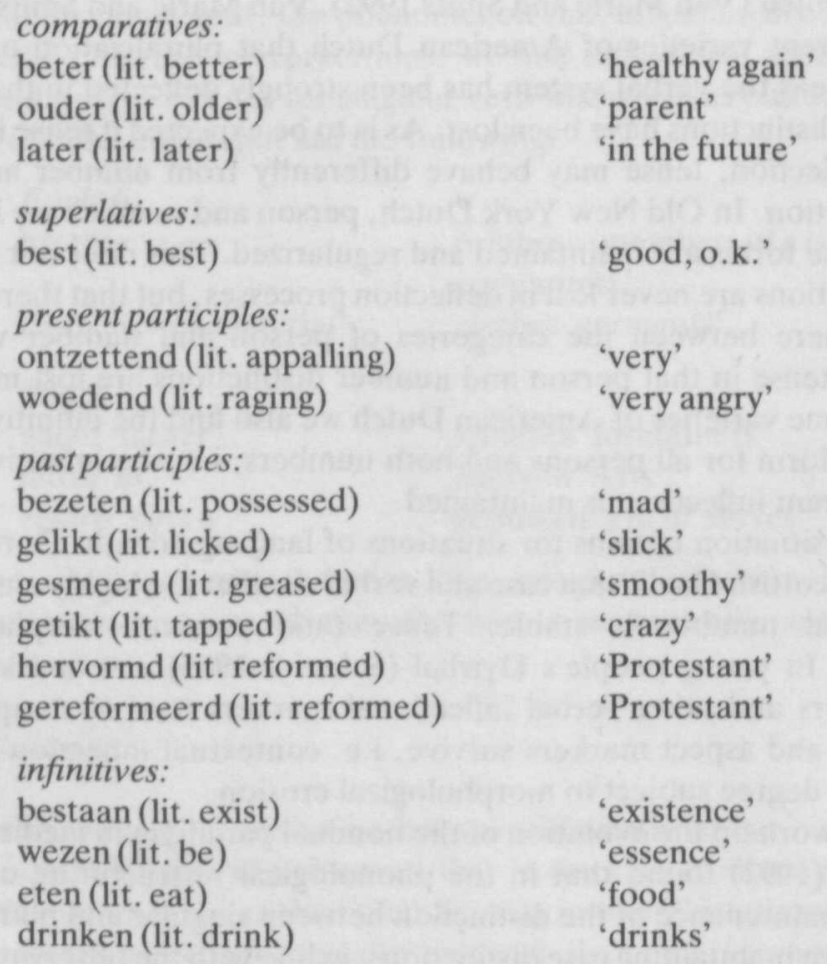

'good, o.k.'

'healthy again' 'parent'

'in the future'

'very'

'very angry'

'mad'

'slick'

'smoothy'

'crazy'

'Protestant'

'Protestant'

'existence'

'essence'

'food'

'drinks'

The fact that infinitives can so easily lexicalize into nouns was also pointed out for the Romance languages by Malkiel (1978), for instance: 
(12) French: repentir 'repentance', parler 'dialect', devoir 'duty', pouvoir 'power'

Rumanian: lucrare 'work', durere 'pain', sosire 'arrival', intindere 'extension'

Malkiel used these observations to illustrate the point that derivation and inflection cannot be sharply distinguished.

The fact that lexicalization clearly distinguishes between inherent and contextual inflection suggests once more that inherent inflection is more like derivation, which is also subject to lexicalization.

\subsection{Affix order}

Generalizations concerning the order of inflectional suffixes can partially be stated in terms of the distinction between contextual inflection and inherent inflection: contextual inflection tends to be peripheral with respect to inherent inflection. For instance, when case and number are expressed by different suffixes, the case suffix is peripheral w.r.t. the number suffix. Greenberg (1963) gives this generalization as Universal 39.

"Universal 39. Where morphemes of both number and case are present and both follow or both precede the noun base, the expression of number almost always comes between the noun base and the expression of case." (Greenberg 1963: 95)

Similarly, Bybee $(1985: 24)$ remarked with respect to the expression of verbal inflectional categories that the expressions for number agreement, person agreement and gender agreement, i.e. the contextual inflectional categories, are peripheral to the morphological expressions of valence, voice, aspect, tense, and mood, i.e. the inherent inflectional categories of the verb.

Yet, contextual inflection is not always peripheral to inherent inflection. For instance, in Welsh Romany the imperfect suffix $-s$ always follows the subject agreement suffix, as in the following forms from the paradigm of kam 'to love': ${ }^{8}$

\begin{tabular}{lllll} 
& \multicolumn{2}{c}{ Present } & \multicolumn{2}{c}{ Imperfect } \\
& Sg & PI & Sg & PI \\
1 & kamáva & kamása & kamáva-s & kamása-s \\
2 & kamésa & kaména & kamésa-s & kaména-s \\
3 & kaméla & kaména & kaméla-s & kaména-s
\end{tabular}

This implies that it is not possible to account for the tendency that contextual inflection is peripheral to inherent inflection in terms of a model of the organization of the grammar in which inherent inflection is located in the lexicon, and contextual inflection in a post-syntactic component of spell out rules. 


\subsection{Agreement}

Agreement phenomena also reflect the difference between inherent and contextual inflection. For instance, whereas case, a case of contextual inflection, plays a role in agreement between specifiers and heads within NP's, it is a rare phenomenon across languages to have case agreement between relative pronouns and their antecedents, which only agree with respect to inherent morpho-syntactic properties such as gender and number. Comrie (1981: 147) mentions Ancient Greek as a language in which the case of the antecedent can be transferred to the relative pronoun, so-called 'attraction'. That this is a marked phenomenon is also clear from the fact that case attraction can also work the other way round, as in Persian where, according to Comrie, the subject of the main clause can be marked as direct object if it is the antecedent of a relative pronoun that functions as direct object in the relative clause.

In sum, agreement phenomena support the distinction between inherent and contextually determined morpho-syntactic properties. The observations given here are also in conformity with Corbett's (1979) agreement hierarchy

$$
\text { attributive - predicate - relative pronoun - personal pronoun }
$$

in which the possibility of syntactic agreement decreases monotonically from left to right, and, inversely, the possibility of semantic agreement increases, since agreement w.r.t. inherent morpho-syntactic categories is more of a semantic nature than agreement with respect to contextually determined, semantically empty, properties.

\section{INHERENT INFLECTION AS INPUT FOR WORD FORMATION}

In this section, I will show that inherent inflection may feed word formation, which leads to the conclusion that the split morphology hypothesis cannot be right.

\subsection{Plural nouns and word formation}

Dutch appears to be one of the languages in which plural nouns can function as input for compounding, as in the following examples (cf. also Booij 1977: 48, 1992):

(16) steden-raad 'cities council' (vs. stadsraad 'city council') minderheden-beleid 'minorities policy'

huizen-rij 'row of houses'

daken-zee 'sea of roofs'

jongemannen-vereniging 'young men's association' 
Note that head constituents like rij, zee en vereniging even require a plural nonhead given the meaning of these words. Similar compounds have been observed for English (Dierickx 1970, Selkirk 1982: 52, Dressler 1989), e.g. arms race, parts distributor, buildings inspector, news man, sports woman, clothes press, roads program, universities yearbook, suggestions box. Note that it is not only irregularly inflected nouns that form inputs for compounding, as was claimed by Kiparsky (1982) in his level-ordered approach of English morphology in which irregular inflection is ordered before, and regular inflection is ordered after compounding. For instance, in buildings inspector, the word buildings is a regular plural noun. ${ }^{9}$

However, one might argue that the occurrence of plural nouns in non-head position does not prove that nominal inflection feeds word formation, since an alternative analysis is available: phrases have to be allowed as non-headconstituents of compounds (Booij 1992, Lieber 1992), as illustrated here for Dutch, and thus we can also have NP's as left constituents of compounds that contain a plural noun only:

$$
\begin{aligned}
& \text { [drie landen }]_{\mathrm{NP}} \text { punt 'place where three countries meet' } \\
& \text { [oude mannen }]_{\mathrm{NP}} \text { huis 'old men's home } \\
& \text { [hete lucht }]_{\mathrm{NP}} \text { ballon 'hot air balloon' }
\end{aligned}
$$

In the first two examples the words landen en mannen are plural nouns. Note that we also find contextual inflection within such word-internal NP's, for instance the final $-e$ of hete in heteluchtballon.

The fact that plural nouns in the non-head position of compounds do not occur as frequently as (seemingly) singular nouns has to do with the fact that compound-internal nouns without an explicit number inflection should not be seen as singular nouns, but rather as nominal stems which are unspecified for number. For instance, in the compound boekverkoper 'book seller' the nonhead boek should not be interpreted as singular noun, but rather as an unspecified one: clearly, a bookseller normally sells more than one book, but this need not be specified.

Italian also has a productive class of (exocentric) compounds containing plural nouns (cf. Zuffi 1981)

$$
\begin{aligned}
& \text { lavapiatti 'dish washer' (piatti = plates) } \\
& \text { portalettere 'post man' (lettere = letters) } \\
& \text { rompiscatole 'brain twister' (scatole }=\text { brains) } \\
& \text { giradischi 'record player' (dischi }=\text { records) } \\
& \text { portaombrelli 'umbrella stand' (ombrelli = umbrellas) }
\end{aligned}
$$

The same type of compound is found in Spanish (Sadock 1991: 158)

$$
\begin{aligned}
& \text { tuca discos 'record player' } \\
& \text { limpia botas 'bootblack' }
\end{aligned}
$$

Note that in these cases the plural noun cannot be interpreted as an NP since NP's are not allowed in that position. For instance, in Italian we cannot form 
porta grandi ombrelli besides portaombrelli (Scalise 1992: 195) as would be expected if the second constituent had phrasal status.

Plural nouns do not only occur in compounds, but also in derived words. This was observed for Dutch in Booij (1977: 48) where the following examples are given of plural nouns to which the collective suffix -dom has been attached:

scholieren-dom 'the set of pupils', ploerten-dom 'the set of cads', muzikanten-dom 'the group of musicians'

The plural forms involved here are regular ones, and the process is productive.

For West-Frisian, a regional dialect of Dutch, Pannekeet (1979) gave examples such as moidjes-ig 'fond of girls (< moidjes 'girls') and peerdjes-e 'to play horse' (< peerdjes 'horses'). The latter example is a case of conversion: plural nouns can be converted into a verbal stem. Other examples are: pakkiese 'to make packets' and klussiese 'to do all kinds of chores'. ${ }^{10}$

Bochner (1984) also argued that inflection cannot be completely separated from derivation, as Anderson would have it. Of his three cases two are no doubt cases of inherent inflection that feed derivation. According to Bochner, Yiddish plural nouns can serve as input for diminutive formation and adverb formation. However, Perlmutter (1988) argued that this only holds for irregular plural formations which for that reason have to be listed in the lexicon, and hence can feed word formation. Perlmutter argues that therefore the Yiddish data do not form counterexamples to the Split Morphology Hypothesis that claims that (regular) inflection is separated from derivation, and dealt with in a separate, post-syntactic component.

Even if Perlmutter were right with respect to Yiddish, it is clear from the above examples that it cannot be considered as a generally valid condition that only irregular inflectional forms serve as input for word formation. This is also shown by Stump (1990) who observed that the Breton diminutive suffix cannot only be attached to singular nouns, but also to regularly inflected plural nouns. Moreover, the comparative and superlative forms of adjectives, two other cases of inherent inflection, can also be diminutivized (data from Stump 1990):

$\begin{array}{llll}\begin{array}{l}\text { singular } \\ \text { bag 'boat' }\end{array} & \text { diminutive } & \text { plural } & \text { plural diminutive } \\ \text { tra 'thing' } & \text { traig } & \text { bagoù } & \text { bagoùigoù } \\ \text { paotr 'boy' } & \text { paotrig } & \text { traoù } & \text { traoùigoù } \\ \end{array}$

bras 'big', brasoc'h 'bigger', brasoc'hik 'a little bigger', brasan 'biggest', brasaikan 'biggest by a little'

Breton plural nouns feed two other derivational processes, the formation of denominal verbs in -in and $-a$, and the formation of denominal adjectives derived by the suffix -ek:

\author{
botez 'shoe' botoù 'shoes' \\ aval 'apple' \\ delienn 'leaf'
}

botaoùin 'to make shoes' avalaoua 'to look for apples' deliaouek 'leafy' 
Note that in (21) pluralization occurs twice, i.e. it applies recursively. The possibility of recursive application is often considered as a characteristic property of derivation as opposed to inflection (Dressler 1989). It appears that in Breton pluralization of nouns can apply twice anyway (Stump 1990: 115):

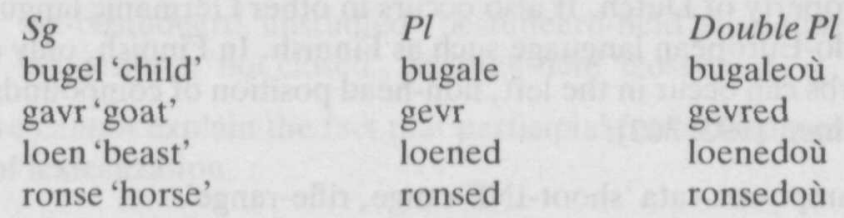

Similarly, Bauer (1983: 26) observed that in Portuguese, plural is sometimes marked twice in diminutives, just as in the Breton words in (23).

\subsection{Infinitives and word formation}

Infinitives in Dutch appear to feed word formation, both compounding and derivation. In compounds they can occur both as left constituents (i.e. in the non-head-position) and as right constituents, i.e. as heads:

(25) a. Infinitives in non-head position:

lijden-s-verhaal 'Passion'

zien-s-wijze 'point of view'

bestaan-s-grond 'reason for existence'

eten-s-tijd 'dinner time'

slapen-s-tijd 'bed time'

sterven-s-begeleiding 'terminal care'

Infinitives in head-position:

school-zwemmen 'school-swimming'

boek-binden 'book-binding'

hout-hakken 'wood-chopping'

touw-trekken 'rope-pulling'

Infinitives have an ambiguous character in that they have both verbal and nominal properties. In the examples (25a) the presence of the linking phoneme $s$ reflects this nominal character. The examples (25b) belong to a productive morphological category although the formation of verbal compounds is unproductive in Germanic languages, again because infinitives also pattern like nouns (Booij 1989). ${ }^{11}$

The use of the infinitival form instead of the verbal stem has to do with the fact that the infinitive form functions here as verbal nominalization. In Dutch, the deverbal nominalizing suffix is -ing, but this suffix hardly ever attaches to underived verbs. For these verbs, the infinitive form is the only possible form of nominalization: nouns like *lijding, "eting, *slaping and "sterving are ill formed. Therefore, verbal infinitives do not occur in the non-head position when derived verbs are involved, for which -ing is available. For instance, 
Dutch has begroetingsceremonie 'greeting ceremony' rather than *begroetceremonie because the derived verb begroeten allows for nominalization with -ing.

The possibility of infinitives feeding compounding is by no means an exclusive property of Dutch. It also occurs in other Germanic languages, and in a non-Indo-European language such as Finnish. In Finnish, only non-finite forms of verbs can occur in the left, non-head position of compounds (Sulkala and Karjalainen 1992: 362):

$$
\begin{aligned}
& \text { ampu-ma-rata 'shoot-INF-range, rifle-range' } \\
& \text { liikku-ma-tila 'move-INF-space, manoeuvring space' } \\
& \text { maa-ta-pano 'lie-INF-put + deriv. suffix, bed time' }
\end{aligned}
$$

In Dutch, infinitives can also feed derivation with -er and -ing but this is a marginal phenomenon, only occurring with some special infinitives with the inflectional ending $/ \mathrm{n} /$ (normally, the inflectional ending is $/ \partial \mathrm{n} /$ :

$$
\begin{aligned}
& \text { doen /du-n/ 'to do' doen-er 'active person', doen-ing 'business' } \\
& \text { zien /zi-n/ 'to see' zien-er 'seer', voor-zien-ing 'provision' }
\end{aligned}
$$

Summarizing, there is substantial evidence that infinitival forms feed word formation.

\subsection{Participles}

In Dutch, present and past participles feed word formation, both compounding and derivation. That is, their morphological distribution is that of adjectives, as is to be expected since they have to be considered as verbal adjectives (note also that in languages with agreement between adjectival specifiers and nominal heads participles behave as adjectives with respect to agreement):

(28) a. Present participles adem[benem-end] 'breath taking' hart[verscheur-end] 'heart breaking' [behoud-end]heid 'conservatism' [doel-treff-end]heid 'effectiveness' on[nadenk-end] 'unthinking'

b. Past participles computer[gestuurd] 'computer-controlled' mens[gericht] 'human-oriented' on[gestuurd] 'un-controlled' [aangepast]heid 'adjustedness' [bewogen]er 'more moved'

Dutch is no isolated case in this respect: in many languages participles can function as adjectives, and thus feed deadjectival word formation processes. Although some of these participles are lexicalized in their adjectival use, this is 
by no means always the case. For instance, the Dutch negative prefix onproductively attaches to regular participles, thus creating negative adjectives. Similarly, the deadjectival suffix -heid '-ness' productively attaches to participles:

$$
\begin{aligned}
& \text { on-bestudeerd 'unstudied', bestudeerd-heid 'studiedness' } \\
& \text { on-gesloten 'not closed', gesloten-heid 'closedness' }
\end{aligned}
$$

That is, we cannot explain the fact that participial forms feed word formation in terms of lexicalization.

\subsection{Comparatives}

It is well known that comparative forms of adjectives (with the suffix -er) can feed derivation. Dutch examples are:

$$
\begin{array}{ll}
\text { oud-er 'older' } & \begin{array}{l}
\text { oud-er-dom 'old age', oud-er-e 'old } \\
\text { person', oud-er-ling 'presbyter', }
\end{array} \\
& \text { ver-oud-er 'to grow old' } \\
\text { jong-er 'younger' } & \text { jong-er-e 'young person' } \\
\text { erg-er 'worse' } & \text { ver-erger 'to make worse' } \\
\text { meerd-er } & \text { ver-meerd-er 'to expand', } \\
& \text { meer-der-e 'superior' } \\
\text { beter 'better' } & \text { ver-beter 'to improve' }
\end{array}
$$

These data support once more the conclusion that word formation must have access to inherently inflected forms. ${ }^{12}$

\section{SPLIT INFLECTION?}

In contrast to inherent inflection, contextual inflection appears to be blocked from feeding word formation. For instance, we do not find inflected verbs or inflected adjectives in the non-head position of Dutch compounds:

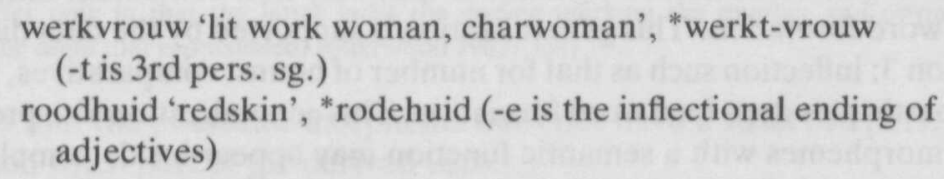

Note that inflected adjectives of course do occur in phrases that are embedded in words, as pointed out above. ${ }^{13}$

This may suggest that inflection should be split into two components, inherent inflection, to be accounted for in the lexicon, and contextual inflection in a post-syntactic component of spell out rules. However, it was already pointed out in section 2.5 that contextual inflection is not always peripheral to inherent inflection (the case of Welsh Romany). Other problems for split inflection are the following: 
- The same morpheme may express both inherent and contextual inflection. For instance, in the inflectional paradigms of Latin nouns the same ending expresses both number (inherent inflection) and case (contextual inflection). Similarly, the verbal endings express both inherent inflection (tense) and contextual inflection (the agreement categories number and person).

- The same inflectional morpheme may sometimes function as contextual inflection, and in other cases as inherent inflection. For instance, the same case morpheme may have either a purely syntactic function, in which the case marking is required by the syntactic context, as in the accusative marking of the direct object Romam in Video Romam 'I see Rome', or a semantic (adverbial) function as in Romam with the meaning 'to Rome'. In many Indo-European languages cases have both a syntactic and a semantic function (Kurytowicz 1964: 181, Babby 1986, Rappaport 1986). In Russian, the use of accusative versus genitive marking of objects corresponds with a semantic difference:

(32) a. Daj nam xleb

Give to-us bread-ACC 'Give us the bread'

b. Daj nam xleba

Give to-us bread-GEN 'Give us some bread'

- in Georgian, preverbal elements with a derivational or inflectional function appear before person/number prefixes, that is, before contextual inflection (Aronson 1982, Bochner 1984).

This leads to the conclusion that restrictions on the interaction of inflection and derivation cannot be accounted for by splitting inflection. Rather, what we need are substantive constraints on how inflection can feed derivation.

\section{CONSTRAINTS ON THE INTERACTION OF INFLECTION AND WORD FORMATION}

The first generalization to be made is that only non-contextual inflection can feed word formation. This generalization is supported by the data discussed in Section 3: inflection such as that for number of nouns, comparatives, infinitives and participles does feed word formation. This generalization also predicts that case morphemes with a semantic function may appear inside complex words. This appears indeed to be the case in Hungarian ${ }^{14}$ (Kiefer 1992: 64), and in Finnish, where case forms productively appear in the non-head position of compounds (Sulkala and Karjalainen 1992: 362 and Merisalo, pers. comm.):

maa-Ita-pako 'country-ABLATIVE-flight, rural depopulation' matka-lla-oloaika 'journey-ADESSIVE-being time, the time that the journey takes'

naimisi-in-meno 'married-ILLATIVE-going 'the fact of getting married' 
Complex words with internal case also occur in Archi, Russian, Turkish (Beard ms.) in Baltic languages (Endzelīns 1971: 81-2), in Icelandic (Jensen and Stong-Jensen 1984), and in Warlpiri and Waramungu (Simpson and Withgott 1986: 153). The latter two languages are of particular interest since here case morphemes are internal to category-changing causative suffixes:

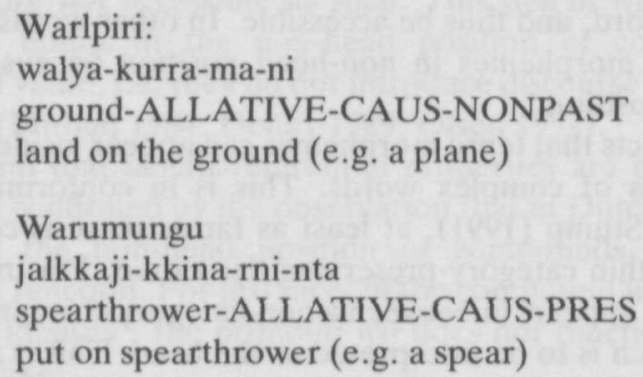

Denny (1989) presents data concerning Eskimo that show that incorporated nouns can be inflected. "The inflections that appear are the local cases and the possessed endings: grammatical case and number endings, which are the most important for syntax, do not occur" (Denny 1989: 239). Relevant examples are the following:

$$
\begin{aligned}
& \text { tursuung-mu-aq-luni 'she is going to the porch' } \\
& \text { porch-ALLATIVE-go-she } \\
& \text { angu-si-sar-poq 'he resembles his father' } \\
& \text { father-POSS-resemble-he }
\end{aligned}
$$

Sherwood (1983), in a squib that aimed to show that inflection cannot always be ordered after derivation, reported for Maliseet that in this Algonquian language, verbs can be derived from possessed nouns. However, he observed that the bases for verb formation are partially inflected possessed nouns:

The third person singular possessed form of the noun and the base of the corresponding verb of possession differ only in that the latter lacks the ending marking the number and obviation categories of the noun that is possessed. (Sherwood 1983: 354)

This implies that the possessor morpheme does not have a strict 3 rd pers. sg. interpretation when part of the derived verb:

$$
\begin{aligned}
& \text { nд-wд-tol-i } \\
& \text { I-POSS-canoe-Verbal suffix }
\end{aligned}
$$

'I have a canoe'

A second constraint on the interaction of inflection and word formation is that tense, although a case of inherent inflection, does not appear in the nonhead position of a complex word. For instance, in Dutch it is impossible to use a past tense form as input for word formation: 
As pointed out above, tense is a deictic category. The generalization therefore seems to be that deictic propeties, in order to be accessible must appear in the head position of complex words. It is only in head position that they can percolate to the whole word, and thus be accessible. In other words, it makes no sense to have tense morphemes in non-head position because tense is uninterpretable in that position.

This explanation predicts that tense morphemes can appear inside words on the morphological heads of complex words. This is in conformity with a generalization made by Stump (1991), at least as far as tense is concerned: inflection can appear within category-preserving derivation. For instance, in Sanskrit, the tense prefix appears in between a non-category changing preverb and the verbal root, which is to be interpreted as the head. This is illustrated here with the verb for 'to marry' in which the past tense morpheme $a$ appears after the prepositional preverb. ${ }^{15}$

$$
\begin{aligned}
& \text { pary-a-nayat 'he married' } \\
& \text { PREVERB-PAST-marry, 3rd pers. sg. }
\end{aligned}
$$

Bochner (1984) who also argued against split morphology, pointed out that in Georgian person/number prefixes occur close to the verbal root, and are preceded by so-called preverbs:

$$
\begin{aligned}
& \text { mo-v-klav 'I will kill him/her' } \\
& \text { FUT-I-kill }
\end{aligned}
$$

Again, since the preverbs do not change category, and hence need not be seen as the head of the complex verbs, deictic categories such as person/ number agreement are expected to be possible on the head of the complex verb. ${ }^{16}$

This constraint also accounts for the observation by Sherwood (1983) discussed above: when a possessed noun is incorporated, the possessor morpheme no longer has a specific 3rd person interpretation. This is to be expected since 'person', whether inherent or contextual inflection, is, like tense, a deictic category. Therefore, we never find verbal forms marked for number feeding word formation. In so-called Pro-drop languages such as Latin that express the subject of a sentence by morphological markings for person and number on the verb, person and number marking are strictly speaking a case of inherent inflection, since these markings are not determined by syntactic context. Yet, such languages do not allow for such verbal forms to feed word formation. This follows from the constraint on deictic elements proposed here since person and number marking on verbs are deictic categories.

That agreement markers for categories such as person and number may be seen as deictic/referential categories is also pointed out by Lehmann (1988: 55): 
[...] agreement is referential in nature. It helps identify or reidentify referents. It does this by giving information on grammatical properties of its referent and thus, of the NP representing it if one is around.

As pointed out above, this explains why such agreement markers do not occur in the non-head position of compounds, because in that position referential elements are not accessible as such. This ties in with the observation that, generally, nouns in the non-head position of compounds do not have referential value, i.e. they do not introduce discourse referents but function as modifiers (Mithun 1984, Denny 1989, Olsen 1992).

The claim that deictic/referential properties are not allowed in non-head position is confirmed by the observation that in Dutch personal pronouns can appear in the non-head position of compounds, but without getting a referential function. For instance, in the compound wij-gevoel 'lit. we-feeling, corporate identity', the pronoun wij does not function referentially, witness sentences like:

$$
\begin{aligned}
& \mathrm{Zij} \text { hebben een sterk ontwikkeld wij-gevoel } \\
& \text { 'They have a strongly developed corporate identity' }
\end{aligned}
$$

with a third person pl. subject to which the wij-gevoel (with a first pers. pl pronoun) is assigned. The same applies to English she-wolf, and words like German Jetztzeit and Danish nutiden 'present'. ${ }^{17}$

\section{CONCLUSIONS}

The evidence presented above leads to the conclusion that the split morphology hypothesis is incorrect. In particular, non-contextual inflection may feed word formation. Inflectional morphology with a deictic nature such as tense, person and agreement morphology, on the other hand, can only appear on the head of the complex word. ${ }^{18}$ Note, by the way, that the set of deictic morphological markers overlaps with both the set of inherent inflectional markers and the set of contextual inflectional markers.

In other words, rather than restricting the interaction between inflection and word formation by completely separating them, as proposed by the Split Morphology Hypothesis, we should allow for inflection to feed word formation, but subject to substantive constraints: inflectional categories of a deictic/referential nature and syntactically determined inflection cannot appear in the non-head position of complex words. The constraint on deictic categories may derive from the more general constraint that the non-head position of complex words cannot function referentially. 


\section{NOTES}

* I thank Mark Aronoff, Laurie Bauer, Andrew Carstairs-McCarthy, Shelly Lieber, Jaap van Marle, and Greg Stump for their very helpful comments on a previous draft of this paper. All usual disclaimers apply.

I For a similar view, cf. Van Marle (1985: 36-37, n. 59).

${ }^{2}$ In the case of the comparative which is qualified here as inherent inflection, one might object that the comparative form is predictable from, and required by syntactic structure, in particular by the phrase than NP. Note, however, that the comparative form also occurs without than-phrase, as in He wanted a bigger share, which shows that it is not syntactic structure that requires the comparative form. It is rather the other way round: the use of the comparative form makes it possible to use a than-phrase.

${ }^{3}$ The distinction between inherent and contextual inflection can also be found in the traditional literature (cf. Knobloch, to appear). For instance, Süterlin (1900: 76) distinguishes between inflection with a purely syntactic function such as case for nouns, and person and number for verbs, and inflection with an independent meaning contribution such as number for nouns, and tense and mood for verbs. The latter type of inflection is considered as similar to derivation.

${ }_{4}$ That is why some morphologists consider plural formation and comparative formation as derivation (cf. Beard 1982, Mugdan 1989).

${ }^{5}$ The tense of a verb may of course be determined by semantic context as in Dutch Toen kwam / "komt hij 'Then he came'.

${ }^{6}$ As Sassen (1992) shows, the class of nouns without a plural form is very large.

${ }^{7}$ The words onder, boven, voor, achter and middel do occur, but not as adjectives.

${ }^{8}$ This fact was brought to my attention by Greg Stump who mentions Sampson (1926) as his source.

${ }^{9}$ It may be true that in English it is mainly (semantically) irregular plurals that occur in the nonhead position of compounds. Nevertheless, as pointed out by Pinker and Prince (1991), the occurrence of regular plurals in that position cannot be excluded.

${ }^{10}$ However, this process may be unproductive.

1 Note also that the infinitival character of these compounds explains why native speakers of Dutch cannot form tensed forms of such compounds, and are indeed reluctant to do so, because that requires reinterpretation of such compounds with infinitival heads as the infinitive forms of verbal compounds, an unproductive category in Dutch (Booij 1989).

${ }^{12}$ Stump (1990: 106-107) shows that in Breton comparative and superlative forms feed diminutive word formation, a process that according to him is either derivation or in between derivation and inflection, but certainly not a case of syntactically relevant inflection.

${ }^{13}$ There are a few words in Dutch such as wittebrood 'white bread' and hogeschool 'lit. high school, college' with inflectional schwas. These words are to be considered as lexicalized NP's, and this class of words cannot be extended. For instance, besides wittebrood we also have the regular ANcompound witbrood 'white bread'.

${ }^{14}$ In Hungarian we find 'compounds' like tévét néz 'lit. television watch, to watch t.v.' with the accusative suffix $-t$. This seems to be a problem for my claim since accusative is a case of structural case. However, as Kiefer points out, there is a number of reasons why these expression are not compounds in the morphological sense but rather phrasal collocations.

15 Note, however, that Stump's generalization may not be correct for all kinds of inflection, since, for instance, Dutch comparatives can be inputs for category-changing derivation, as shown in section 3 .

${ }^{16}$ According to Bochner (1984: 414) similar configurations of facts are found for a number of Amerindian languages.

17 Examples from Laurie Bauer (pers. communication).

${ }^{18}$ These conclusions only pertain to word formation. It may be the case that the theory of grammar also has to allow for affixes that are attached at the syntactic level. This applies in particular to affixes that nominalize or relativize phrases or clauses (Rice 1985, Hoekstra 1986, Kari 1992). 


\section{REFERENCES}

Anderson, S.R. 1982. "Where's Morphology?" Linguistic Inquiry 13, 571-612.

Anderson, S.R. 1988a. "Inflection". In M. Hammond and M. Noonan (eds.), Theoretical Morphology. Approaches in Modern Linguistics. San Diego etc.: Academic Press, 23-44.

Anderson, S.R. 1988b. "Morphological Theory". In F.J. Newmeyer (ed.), Linguistic Theory: Foundations. I. Cambridge: Cambridge University Press, 146-191.

Anderson, S.R. 1992. A-morphous Morphology. Cambridge: Cambridge University Press.

Aronoff, M. 1991. "Noun Classes in Arapesh". In Booij and van Marle (eds.), 5-20.

Aronson, H. 1982. Georgian. A Reading Grammar. Columbus, Ohio: Slavica Publishers.

Babby, L. 1986. "The Locus of Case Assignment and the Direction of Percolation: Case Theory and Russian". In R.D. Brecht and J.S. Levine (eds.), Case in Slavic. Columbus, Ohio: Slavica Publishers, 170-219.

Badecker, W. and A. Caramazza 1989. "A Lexical Distinction Between Inflection and Derivation". Linguistic Inquiry 20, 108-116.

Baker, M. 1991. "Morphological Classes and Grammatical Organization". In Booij and van Marle (eds.), 89-106.

Barnes, A.S.V. $1991^{30}$ Afrikaanse Grammatica. Kaapstad: Nasou Beperk.

Bauer, L. 1983. English Word Formation. Cambridge: Cambridge University Press.

Beard, R. 1982. "The Plural as a Lexical Derivation". Glossa 16, 133-148.

Beard, R. ms. Lexeme-Morpheme Base Morphology. Bucknell University, Lewisburg PA.

Bochner, H. 1984. "Inflection within Derivation". The Linguistic Review 3, 411-421.

Booij, G.E. 1977. Dutch Morphology. Dordrecht: Foris.

Booij, G.E. 1989. "Complex Verbs and the Theory of Level Ordering". In G.E. Booij and J. van Marle (eds.), Yearbook of Morphology 1989. Dordrecht: Foris, 21-30.

Booij, G.E. 1992. "Compounding in Dutch", Rivista di Linguistica 4, 37-59.

Booij, G.E. and J. van Marle (eds.) 1991. Yearbook of Morphology 1991. Dordrecht: Kluwer Academic Publishers.

Bybee, J. 1985. Morphology, Amsterdam: John Benjamins.

Combrink, J.G.H. 1990. Afrikaanse Morfologie. Pretoria: Academica.

Comrie, B. 1981. Language Universals and Linguistic Typology. Oxford: Blackwells.

Corbett, G.C. 1979. "The Agreement Hierarchy". Journal of Linguistics 15, 203-224.

Denny, P.J. 1989. "The Nature of Polysynthesis in Algonquian and Eskimo". In D.B. Gerdts and K. Michelson (eds.), Theoretical Perspectives on Native American Languages. Albany: SUNY Press, 230-258.

Dierickx, J. 1970. "Why Are Plural Attributives Becoming More Frequent?" In J. Dierickx and Y. Lebrun (éds.), Linguistique Contemporaine. Hommage à Eric Buyssens. Bruxelles: Editions de l'Institut de Sociologie, Université Libre, 39-46.

Dorian, N. 1981. Language Death. The Life Cycle of a Scottish Gaelic Dialect. Philadelphia: University of Pennsylvania Press.

Dressler, W.U. 1989. "Prototypical Differences Between Inflection and Derivation". Zeitschrift für Phonetik, Sprachwissenschaft und Kommunikationsforschung 42, 3-10.

Endzelins, J. 1971. Comparative Phonology and Morphology of the Baltic Languages. The HagueParis: Mouton.

Greenberg, J.H. 1963. "Some Universals of Grammar with Particular Reference to the Order of Meaningful Elements'. In id. (ed.), Universals of Language. Cambridge Mass.: MIT Press, 73$113\left[1966^{2}\right]$

Halle, M. 1973. "Prolegomena to a Theory of Word Formation". Linguistic Inquiry 4, 3-16.

Hoekstra, T. 1986. "Deverbalization and Inheritance". Linguistics 24, 549-584.

Jakobson. R. 1957. "Shifters, Verbal Categories and the Russian Verb". Selected Writings II. Word and Language. The Hague: Mouton, 1971, 130-147.

Jensen, J. and M. Stong-Jensen 1984. "Morphology is in the Lexicon!". Linguistic Inquiry 15, 474498. 
Kiefer, F. 1992. "Compounding in Hungarian". Rivista di Linguistica 4, 61-78.

Kiparsky, P. 1972. "Explanation in Phonology". Reprinted in id., Explanation in Phonology. Dordrecht: Foris, 1982, 81-118.

Kiparsky, P. 1982. "From Cyclic Phonology to Lexical Phonology". In H. van der Hulst and N. Smith (eds.), The Structure of Phonological Representations Part 1. Dordrecht: Foris, 131-176.

Kari, J. 1992. "Some Concepts in Ahtna Athabaskan Word Formation". In M. Aronoff (ed.), Morphology Now. Albany: State University of New York Press, 107-32.

Knobloch, C. (to appear) "Schulgrammatik als Modell linguistischer Beschreibung". In G.E. Booij, Ch. Lehmann and J. Mugdan (eds.), Handbook of Morphology. Berlin: Walter de Gruyter.

Kurytowicz, J. 1964. The Inflectional Categories of Indo-European. Heidelberg: Carl Winter Universitätsverlag.

Lass, R. 1990. "How to Do Things with Junk: Exaptation in Language Evolution". Journal of Linguistics 26, 79-102.

Lehmann, Ch. 1988. "On the Function of Agreement". In M. Barlow and C.A. Ferguson (eds.), Agreement in Natural Language. Stanford: Stanford University Press, 55-65.

Lieber, R. 1992. Deconstructing Morphology. Chicago: University of Chicago Press.

Malkiel, Y. 1978. "Derivational Categories". In J.H. Greenberg (ed.), Universals of Human Language Vol 3, Word Structure. Stanford: Stanford University Press, 125-149.

Marle, J. van 1985. On the Paradigmatic Dimension of Morphological Creativity. Dordrecht: Foris.

Marle, J. van and C. Smits 1992. "The Inflectional Systems of Overseas Dutch". In Proceedings of the IXth Int. Conference on Historical Linguistics. Amsterdam: Benjamins.

Marynissen, A. 1992. "Morfofunctionele Aspecten van de Substantiefflexie in het 13e-eeuws Ambtelijk Nederlands". Paper presented at the Morfologiedagen 1992, University of Leiden.

Matthews, P.H. 1974. Morphology. Cambridge: Cambridge University Press.

Mithun, M. 1984. "The Evolution of Noun Incorporation". Language 60, 847-879.

Mugdan, J. 1989. "Rev. of Laurie Bauer, Introducing Linguistic Morphology". In G.E. Booij and J. van Marle (eds.), Yearbook of Morphology 1989. Dordrecht: Foris, 175-183.

Olsen, S. 1992. "Zur Grammatik des Wortes. Argumente zur Argumentvererbung", Linguistische Berichte 137, 3-32.

Pannekeet, J.A. 1979. Woordvorming in het Hedendaags Westfries. Amsterdam: Rodopi

Perlmutter, D.M. 1988. "The Split Morphology Hypothesis: Evidence from Yiddish". In M. Hammond and M. Noonan (eds.), Theoretical Morphology. San Diego etc.: Academic Press, 79-100.

Pinker, S. and A. Prince 1991. "Regular and Irregular Morphology and the Psychological Status of Rules of Grammar". In: Proceedings of the 1991 Meeting of the Berkeley Linguistics Society.

Plank, F. 1981. Morphologische (Ir-)Regularitäten. Tübingen: Gunter Narr Verlag.

Rappaport, G. 1986. "On the Grammar of Simile: Case and Configuration". In R.D. Brecht and J.S. Levine (eds.), Case in Slavic. Columbus, Ohio: Slavica Publishers, 244-279.

Rice, K. 1985. "On the Placement of Inflection". Linguistic Inquiry 16, 165-171.

Sadock, J. 1991. Autolexical Syntax. A Theory of Parallel Grammatical Representations. Chicago and London: The University of Chicago Press.

Sampson, J. 1926. The Dialect of the Gypsies of Wales. Oxford: OUP [repr. 1968].

Sassen, A. 1992. "Meervoudloosheid en indeling van Nederlandse zelfstandige naamwoorden". In H. Bennis and J.W. de Vries (ed.), De Binnenbouw van het Nederlands. Een Bundel Artikelen voor Piet Paardekooper. Dordrecht: ICG Publications, 329-341.

Scalise, S. 1986. "Inflection and Derivation". Linguistics 22, 561-581.

Scalise, S. 1992. "Compounding in Italian". Rivista di Linguistica 4, 175-200.

Schmidt, A. 1985. Young People's Dyirbal. An Example of Language Death from Australia. Cambridge: Cambridge University Press.

Selkirk, E.O. 1982. The Syntax of Words. Cambridge Mass.: MIT Press.

Sherwood, D.F. 1983. "Maliseet Verbs of Possession". Linguistic Inquiry 14, 351-356.

Simpson, J. and M. Withgott 1986. "Pronominal Clitic Clusters and Templates". In H. Borer (ed.), The Syntax of Pronominal Clitics. Orlando etc.: Academic Press, 149-174. 
Stump, G.T. 1990. "Breton Inflection and the Split Morphology Hypothesis". In R. Hendrick (ed.), The Syntax of the Modern Celtic Languages (Syntax and Semantics \# 23). San Diego etc.: Academic Press, 97-119.

Stump, G.T. 1991. "A Paradigm-Based Theory of Morphosemantic Mismatches". Language 67, $675-725$.

Sulkala, H. and M. Karjalainen 1992. Finnish. London and New York: Routledge.

Süterlin, L. 1900. Die deutsche Sprache der Gegenwart. Leipzig: Voigtlander.

Watters, J. 1985. "The Place of Morphology in FG: The Case of the Ejagham Verb System". In M. Bolkestein et al. (eds.), Predicates and Terms in Functional Grammar. Dordrecht: Foris, 85104.

Zuffi, S. 1981. "The Nominal Composition in Italian. Topics in Generative Morphology". Journal of Italian Linguistics 2, 1-54.

Vakgroep Taalkunde, Vrije Universiteitl

Holland Institute of generative Linguistics, De Boelelaan 1105, 1081 HV Amsterdam, The Netherlands.

e-mail: booij@jet.let.vu.nl 


\title{
Verbal prefixes in Dutch: a study in lexical conceptual structure
}

\author{
ROCHELLE LIEBER and HARALD BAAYEN
}

\section{INTRODUCTION}

The subject of our study is verbal prefixation in Dutch; specifically we will be concerned with the prefixes ver-, be- and ont-illustrated in (1)-(3):

(1) ver-
a. ver+A verarmen 'to become, make poor'
b. ver $+\mathrm{N}$ verhuizen 'to move'
verpakken 'to wrap up'
vermommen 'to disguise (lit. put a mask on)'
verijzen 'to ice up'
verharen 'to shed hair'
verwormen 'to be eaten by worms'
c. ver+V verspringen 'to spring away'
verjagen 'to chase away'
versmelten 'to melt together (inchoative or
causative)'
verwaaien 'to blow away'
verdobbelen 'togamble away'
vervallen 'to fall to ruin'
vertatoeeren 'to ruin by tatooing'
verdwalen 'to get lost'

(2) be-
a. be+A bekorten 'toshorten'
b. be $+\mathrm{N}$ bebossen 'to forest'
c. be $+\mathrm{V}$ bebouwen 'to build up'

(3) ont-
a. ont $+\mathrm{A}$ ontmenselijken 'to dehumanize'
b. ont $+\mathrm{N}$ onthoofden 'to behead'
c. ont $+\mathrm{V}$ ontketenen 'to unchain'
ontlopen 'to get away from, outrun, escape'
ontbranden 'to ignite' 